\title{
The "Mounth". Passes over the grampians
}

\section{G. M. Fraser}

To cite this article: G. M. Fraser (1920) The "Mounth". Passes over the grampians, Scottish Geographical Magazine, 36:3, 169-180, DOI: 10.1080/00369222008734318

To link to this article: http://dx.doi.org/10.1080/00369222008734318

册 Published online: 27 Feb 2008.

Submit your article to this journal $\pi$

山 Article views: 10

Q View related articles ¿ 
might have taught us from it, had that unerring instrument but been on the spot to immortalise scenes of which written pages give us but a faint idea! One satisfactory thing I can record, and that is, that many of the officers who have figured in the campaigns in Mesopotamia and Persia have since joined the Central Asian Society, and from them we look forward to having graphic descriptions of the life and scenes in which they have played a notable part. Among others who came across was the Reverend Dr. Wigram, for years a missionary among the Nestorian Christians, who, whatever the failure of the Persian, Armenian, Georgian, and Tartar, have well held their own against the Turk. Wo have but recently heard of the death of the Nestorian Patriarch, Mar Thurion, largely from the hardships which he had to endure when heroically leading the Jelu army against the Turk. It is his sister who, in 1918, won by her bravery and devotion the sobriquet of "The Nestorian Jeanne d'Arc."

In conclusion let me reproduce here Major Donohoe's picture of the leader of "Dunsterforce," Major-General L. C. Dunsterville, C.B., A.D.C.

"The original of Kipling's 'Stalky' is keen-witted, with an illimitable fund of dry racy humour. . . One of his obiter dicta was that every British officer in Persia should be compelled to pass a qualifying examination in Hadji Baba-the Oriental Gil Bas-for he would then know more about the Persians, their manners and customs, than could be acquired by months of travel and unaided observation. 'Stalky' had no fear of personal danger. It is related of him that at his fateful interview with the Bolshevists on the occasion of his raid on Resht he told the 'Red Committeo' so many amusing stories in their own mothertongue that many quite forgot the principal business of the evening, which was to sentence him to death." If any one would understand what, in addition to Bolshevists, Jangalis, and Persians, rendered General Dunsterville's mission to the Caspian one of difficulty, let him read Major M. H: Donohoo's IVith the Persian Expedition, pp. 62, 122, $132-3$, and 138 .

\section{THE “MOUNTH". PASSES OVER THE GRAMPIANS."}

By G. M. Fraser, Librarian, Public Library, Aberdeen.

\section{Cairn-a'-Mounth.}

"This passes from Fittircairne in the Mearns to Kincardyne of Neill one Dee, in Mar, and conteins aucht myles in mounthe."

It was an important cross-country road. Like the name of Clochnaben (properly Clach-na-Beinne), which refers primarily not to the hill but to the stone, the usual designation of Cairn-a'-Mounth is a misnomer, for the name does not signify either a road or a hill, but the 
cairn of the hill (as Clach-na-Beinne is the Stone of the Hill), and the route doubtless became known from its most prominent feature.

As the most celebrated of the passes over the Grampians the Cairn$a^{\prime}$-Mounth road has often been described. It is the only one of all these historical passes through the lower range of the Grampians that has continued in what may be termed full use as a cross-country road. It may be compared with Carter Fell over the Cheviots, and, although much less used than Carter Fell for wheel traffic, it is a splendid walking road throughout the summer months.

The Cairn-a'-Mounth road seems to have been made use of by Edward I. of England on his return journey in 1296 after his visit to Aberdeen and the north of Scotland. We have seen that on his journey northward he travelled, with his forces, by way of Cryne's Cross Mounth to Durris and thence to the town. After six days in Aberdeen he went to Kintore, Fyvie, Banff, Cullen, Elgin, and Rothes. On Wednesday, 1st August, he was at Kildrummy, and at Kincardine O'Neil, at the hospital of which he passed the night. On the following day he was at the Castle of Kincardine in the Mearns, his direct course boing by the Cairn-a'-Mounth road. ${ }^{1}$ King Edward made a second journey to the north of Scotland in 1303 . His route in approaching Aberdeen it is impossible to trace. On Monday, 19th August, he was at the Castle of Kincardine in the Mearus. Where he was on Tuesday is not known. On Wednesday he was at Glenbervie. Thursday is a blank. On Friday, 23rd, he is set down as having been at "Haghenhauer" and Aberdeen, where he stayed an indefinite number of days. The probability is that as he travelled from Glenbervie, and was not on this occasion "among the mountains," he came to Aberdeen directly by the Cowie Mounth. After visiting Banff, Cullen, Rathven, Elgin, Kinloss, and various other places in Speyside, Edward is again at Kildrummy, on his way south, on Wednesday, 9th October. The diary of his movements now becomes very defective. We are only certain that on Sunday, $13 \mathrm{th}$, he is at Fettercairn, and on the 16 th he is at Dundee. Again he evidently took the direct route to Kincardine Castle and Fettercairn by the Cairn-a'-Mounth that he travelled seven years before.

The Cairn-a'-Mounth road was in good use throughout history, so far as occasional glimpses of its use enables us to judge, and we have substantial evidence of the fact in the provision of the Bridge of Dye, that carries the bigbway over the Dye Water, which is now the oldest bridge in the whole valley of the Dee except the Bridge of Dee at Aberdeen. Prior to the erection of the bridge the Ford of Dye was at that spot, and was evidently well known. ${ }^{2}$ The bridge was provided

I See Gough's Itinerary, ii. 143-4. As to the claim that King Edward travelled by the Fir Mounth road, see p. 17t. That seems quite erroneous.

2 "In a remote and rude age," says Rev. D. S. Fergusson, minister of Strachan, in 1812 , "the Cairn o' Mount road, the great line of communication across the Grampians, was haunted by a lawless banditti. ... About a century and a half ago (as is related) a highlander passing to the south was obliged to stop at a smith's shop at Ford of Dye, near where the present bridge stands." New Statistical Account of Scotland, xi. (2), p. $239 n$. 
mainly by Sir Alexander Fraser of Durris, who owned the lands of Glen Dye, about 1680 , and this interesting structure, with its ribbed arch, after the manner of the Bridge of Dee and certain others of the older bridges of Scotland, has discharged its function in that remote spot for nearly' 250 years. The only definite information relative to the bridge is contained in two Acts of the Scots Parliaments of Charles II. and James VII. The first, of date 1681, runs :-

"The Kings Majestie and Estates of Parliament, having considered a Petition presented by Andrew ffrazer of Kinmundie Representing That wheras by the liberal and charitable contribution of the deceist Sir Alexander ffraser of Doores Baronet ${ }^{1}$ and of the deceist Mr. George Meldrum, Jate Minister of Alfoord, And the industry, great pains, and expence of the Petitioner, ther is of late Ane stonebridge of Asclerwork of a large extent of fyftie foot diameter erected over the water of Dye upon the publict road that crosseth the Cairne of Mounth, Which Bridge standeth upon one of the most impetwous waters within the Kingdom wher many have perished, And as this bridge was a most necessary work, so lykways it is subject to great and sudden Innundations and danger of being spoyled by storms, And therefore ther is a necessitie of a yeirly supplie an $d$ continual attendance to prevent its ruine, Wheras there is no stock to that end, ffor the money mortified by the said Minister was only Two Thousand Merkes, which scarce served to pay the Maisons builders of the said Bridge, Albeit at their entry the stones were all hewin, And all other materials and service laid to their hands, And it being usuall in such caices, Wher ther is no stock to vphold Bridges, that Parliaments grant Warrands to such persons upon whose ground these Bridges stands, or who have been instrumental in building them to collect from travellers and passengers Ane small toll from men, horse, and Cattell crossing therat for vpholding the work, And supplicating that ordor and Warrant might be granted to the Effect vnderwritten; The Ki gs Majesty and Estates of Parliament Having heard and considered the forsaid Petition and Report of the Articles thereanent, Doe hereby grant, ordor and Warrant to the said Andrew ffraser, Petitioner to exact and vplift at the Bridge of Dye, for vpholding of the said Bridge, the small customs. vnderwritten for the space of Nynteen yeers after the date hereof, viz. for each sadled horse and his ryder, or each horse with a Burden, Eight pennies scots money, And for each man or woman, or each horse, ox, cow (four sheep) or other small beast, ffour pennies money foirsaid, With power to the said Petitioner to appoint a Collector for vplifting therof, He having found sufficient Caution that what shall be so vplifted shall be employed to the use above mentioned." 2

The upliftings of the toll on the Bridge of Dye proved, however, unexpectedly difficult. Persons using the roads and bridges in 1681 were no more willing than their successors in the days of turnpikes to pay toll if they could avoid it. Accordingly, instead of using the new bridge over the Dye and paying the toll, travellers on the Cairn-a' Mounth road forded the stream when it was at all possible, and evaded their just oharges. In 1685, therefore, Sir Peter Fraser of Durris, son

1 For whom Fraser of Kinmundie, his nephew, was factor.

2 Acts of the Parliaments of Scotland, viii. 364. 
of Sir Alexander who provided the bridge, petitioned Parliament to the following effect :-

"And now seeing that, by experience of collecting at the said Bridge, the searly toll forsaid doth not amount to tuentie pound Scots by reason the Water is but small, except at extraordinary times, And the Bridge, lying in a mountainous place is not so much frequented except at certain Seasons and when there is no speat of Waters it is easily fordable, albeit the water when in speat is a great torrent and Damnefies the bridge exceedingly, It being therfor requisit that for the supply of the said Bridge the toll foirsaid be perpetual As to other bridges in the same case And that the samen toll should, after expyring of the nynteen yeares for which it was first granted be therafter payable to your suppliant, his aires and successors, heretors of the Lands upon which the said bridge stands to be by them expended for the use of the said bridge." 1

This petition, like the other, was granted, but for how long the toll was exacted nobody can tell. No one in that region now has any recollection or knowledge of a toll having been charged on the Bridge of Dye. Yet it has been kept up admirably through these two centuries and $a$ half, and will doubtless carry the Cairn-a'-Mounth road over this impetuous mountain stream for many a year to come.

Through all these centuries the Cairn-a'-Mounth was a. main road from Edinburgh to the north country. By Taylor and Skinner, 1776, we trace it as the Edinburgh to Fochabers road-over by Fettercairn and the Bridge of Iye, then across the Feugh at Whitestones, and over the hill, as at present, by the "shooting greens," to the boat and ford of Inchbare, Potarch. The ancient crossings at Inchbare continued to be used till the erection of the present fine granite bridge of Potarchdesigned by Telford-the foundation of which was laid in 1812. On the north side of the Dee the road went by Kincardine O'Neil, Lumphanan, and Torrie to Kildrummy, the chief seat of the Earl of Mar, the most historical stronghold in all the north country. A branch of the road went from Lumphanan directly northward by Alford, the Kirktown of Tullynessle, and Gartly to Huntly, Keith, etc., and was probably far more used than the other in the period of the large cattle trysts.

After crossing the Mounth and the Bridge of Dye the Cairn-a'Mounth road forked as it still does, the branch road striking northeastward over the Dye by the Bridge of Bogendreep to the side of the Feugh opposite the church of Strachan. Thence it ran, as at present, along the right bank of the Feugh---there was no bridge at Strachan then - by Mill of Cammie, to the boat and ford over the Dee at Banchory. From Banchory Church the road joined the Monymusk road by Mill of Hirn, and so to Old Rayne, where, as already explained, it joined the road from Aberdeen to Huntly. ${ }^{2}$

\section{Forest of Birse Mounth.}

This leads from "Cairn Corsse" to Birse, "sex myles of mounthe,"

1 Acts of the Parliaments of Scotland, viii., 496.

2 Taylor and Skinner, plates 29 and $30 . \quad 3$ View of the Diocese, as above, p. $77 \mathrm{n}$. 
and seems to be the road that, leaving the Cairn-a'-Mounth road near Feughside Inn, struck north-westward over the Birse hills slightly.east of Finzean House, and thence passed, as at present, through the village of Marywell, and so on to Birse Church and the bridge over the Dee at Aboyne. It has "sex myles of mounthe," and, generally, is an old line of road. Near the summit is the triangular artificial cairn that may have given the road its name, for near by is the more noted "CorseDardar" stone, or Cross of Dardanus, set up by the roadside. The stone is clamped with iron clasps in a careful way. About the middle of last century, when the road was being shifted, the workmen broke the stone in two, but Archibald Farquharson of Finzean, the proprietor, had it carefully mended and set up as it is now. ${ }^{1}$ It was along this road that Queen Victoria and the Prince Consort drove, towards Balmoral, on 21st September 1861. Formerly the road led to the ferry $\dot{0}$ near the site of the Bridge of Aboyne. According to Dinnie, historian $\infty$ of Birse, there was a ferry-boat and ford a mile or thereby east of the ô bridge. ${ }^{2}$ This must have been so, for near the farm of Waterside there are evidences of a ferry, and the farm people still speak of the tradition ก. of a ferry at that spot.

\section{Mounth Gammel, or Fir Mounth.}

Leading from Glen Esk to Glen Tanner, this “contains sex myles of mounthe," and is the well-known Fir Mounth, named so in later times, $\Sigma^{\pi}$ doubtless, from the noted fir woods in Glen Tanner, and the traffic in these by floaters on the Dee. ${ }^{3}$

Starting from Tarfside, in Glen Esk, this well-used pass ascended by the east side of the Hill of. Cat, thence, holding in a slightly northwesterly direction, it crossed the hill of Craigmahandle, and descended into Glen Tanner. In the General Wade period it was improved as a military road, and it is still a grand walking road over the hills. On coming down the mountain side into Glen Tanner a branch of the road struck down, on the left, to what was known, three-quarters of a century ago, as the "Fir Mounth Stile," at a wooden bridge, where the - stone bridge is now, near Glen Tanner House. The main road came down to the flat bottom of the glen farther east, near the old cottage that the late Sir William C. Brooks, of Glen Tanner, transformed into an Episcopal Chapel, in the graveyard of which he was buried on his

1 History of Birse, by Robert Dinnie, p. 119. The road is always spoken of in the locality as the Corse-Dardar Road.

2 Ibid., p. 49.

3 Glen Tanner "is, indeed, but one great forest of tall firs, belonging to the Earl of Aboyne." View of the Diocese, p. 633 . Rev. W. Robertson, writing in 1725 of that region, says:- "The country is mountainous, not very fertile, the people living more by traffiquing in timber than husbandry, this timber they have from the wood of Glentanar, which lies on the south side of the said Parish and is the only ornament of the place. It is very large in extent, and 10 or 12 miles in circumference, tho' not full in all places. The timber in this wood, which is all fir, grows to a great height and bigness, the whole country round about being served in fir-timber out of it, to the considerable advantage of the Earl of Aboyn who is Heretour of it as he is of al that Parish."-Geographical Collections by Walter Macfarlane, Scot. Hist. Soc., i. 106. 
death in $1900{ }^{1}$ Presently, the road crosses the Tanner by the high single-arch (military) bridge. A branch struck down Glen Tanner, by the south side of the stream, to the Dee, crossing at Aboyne. The main road held northward, however, over the hill between the Tanner and the Dse by Tillycairn - where much diversion of the roads took place at the instance of Sir William C. Brooks-and while a branch struck off to the right to cross the Dee near Glen Tanner.Church, "The Black Chapel in the Muir" (of which only the west gable remains standing), the main road crossed the river slightly farther west. There it connected with the road to Tarland and Kildrummy, as also with the more westerly road that runs by the east side of Morven and the Birkhill Pass to Strathdon. On the road at the hill-top near Tillycairn is a roughly-squared granite memorial erected by Sir William C. Brooks, with the inscription :-

\author{
FIR MVNTH \\ ANCIENT PASS OVER THE GRAMIPIANS \\ HERE CROSSED THE INVADING ARMIES OF \\ Eidward 1. of England \\ A.D. \\ 1296 AND 1303 \\ ALSO THE ARMY OF MONTROSE \\ 1645
}

This inscription, unfortunately, is quite inaccurate as regards King Edward of England, and it is almost certainly inaccurate also as regards Montrose. King Edward, as already explained, crossed the Mounth four times, twice in 1296 and twice in 1303 . In 1296 he crossed first at Durris, and secondly, in going from Kildrummy to Kincardine O'Neil (one day), and to the Castle of Kincardine in the Mearns (next day), he almost certainly went by the direct road, the Cairn-a'-Mounth. In 1303 he went from Glenbervie to Aberdeen, and although the record is defective there is no evidence that he went otherwise than by the Cowie Mounth. As to his return journey the record is again defective, but he went from Kildrummy to Fettercairn, and to go by the Fir Mount would have taken him a roundabout way, and past his objective. The probability-practically a certainty - is that he returned south by Kincardine O'Neil and the Cairn-a'-Mounth as he did on the previous occasion.

As to Montrose, he was not appointed Lieutenant-General for the King in Scotland till 1644, and he did not appear in this region at the head of a Royalist army till 11 th September 1644, when he crossed at Durris, two days before he destroyed the Aberdeen defence at the Crabstone Rout. Repeatedly after that, in 1644 and 1645, Montrose crossed the Mounth, but while his route is sometimes doubtful, it was never probably by the Fir Mounth. On every occasion he seems to have crossed from one open region to another, on either side of the

1 Half a century ago this was the house of the miller in Glen Tanuer. The gravestone of Sir William C. Brooks, in the little graveyard, is a reproduction of the remarkable Celtic cross still standing in the woods of Aboyne Castle. 
Grampians, but the Fir Mounth at its southern end is subordinate to the long Glen Esk, most unsuited to the dashing movements by which Montrose's leadership were distinguished. ${ }^{1}$

As the Fir Mounth road, in its northward course, reached the Hill of Cat, at a height of over 1800 feet, a branch track struck off to the right that has long had the curious name of the Fungle Road. While the Fir Mounth held slightly to the north-west, the Fungle Road struck slightly to the north-east, and, passing the old Castle of Birse-now repaired and reoccupied-at the head waters of the Feugh, it wound round the west shoulder of Carnaferg, and moved down the long northern slope by the Allt-Dinnie to the crossing of the Dee at Aboyne. Only three to four miles separated the crossing of the Dee by the Fungle Road and the crossing by the Fir Mounth route, on the west, but the Fungle seems also to have been used to a considerable extent. The northern end, along the Allt-Dinnie, was put in order by Sir William C. Brooks, and is a favourite walk with summer visitors to Aboyne and district. The rest of the old track, through the moor, is in bad order, but quite sufficiently good for walking.

\section{Mounth Keen.}

This route runs" "from Innermarkie to Canakyle, on Deeside, and containes ten myles of monthe."

This well-known pass is sometimes called "The Mounth," from the fact that it is the highest of the main roads over the Grampians, reaching to within the 2500 contour line on the west shoulder of Mount Keen. From Glen Mark the pass ascended Mount Keen, as just mentioned, to the height of 2500 feet. Dipping quickly down the north-west shoulder of the mountain into Glen Tanner, and crossing the Tanner by a ford-near which the remains of the public-house of Cuirriebhruaich are easily distinguishable - the road ascends the northern ridge by what in recent years was a well-made path to the moss near the Pollagach Burn, between Cairn Leughan and Knockie Branar. From the north-west side of the moss traffic by the Mount Keen route passes downward by a good moss road, made about three-quarters of a century ago, that leads down through the gate in the deer fence and the policies of Glenmuick House, to issue on what is now the Ballater Road at the east end of the Bridge of Muick. Prior to the making of the moss road, however, the Mount Keen track struck northward by the east end of the moss, and through what is now the Braiklie Wood in an almost direct line towards Ballater. This part of it was the."Kirk

1 One of Montrose's crossings that has been rather misunderstood was his crossing the Mounth southward after the battle of Alford, 2nd July 1645. He was clearly at Craigton, near the Hill of Fare, and what are said to be Montrose's entrenchments are still shown near Craigton farm. His clear and clirect route from Craigton to Fordoun was not by the - Loch of Skene and the Culter Ford, as has been suggested, but by Crathes and Cryne's Cross Monnth, which he had formerly used, and was the shortest, or by the Cairn-a'Mounth.

2 The highest pass actually in the British Isles is that from Glen Is]a over the shonlder of Glas Maol to the Cairnwell, reaching an altitude of 3300 feet above sea-level. 
Road" for the dwellers at Etnach and Coirriebhruaich in the upper part of Glen Tanner. From Glen Muick the Mounth Keen road would lead eastward over the shoulder of Culblean and Coldstone to the Birkhill Pass and Strathdon; or, turning westward, it would lead by Glen Gairn to the Fort George road by Tornahaish, Corgarff, and Tomintoul. ${ }^{1}$

\section{Capel Mounth.}

This leads from Clova to Glen Muick, and "conteins twelve myles of monthe."

The name of this pass may seem a little puzzling. It is not Gaelic. As already remarked, none of these Mounth road names derives directly from the Gaelic. The old Gaelic inhabitants did not name roads-they had none to name. Like many similar names in Scotland, Chapelton, Kepplehills, and so on, that always indicate the site of a chapel, the name of the Capel Mounth tells of a chapel (cappella) in that region. ${ }^{2}$ The name of Spital of Muick, near the northern end of the pass, supplies the key. Here the Bishop of Aberdeen established an hospice or hospital-which would have its chapel-hence the name of the Capel Mounth and of the Capel Burn, Glen Clova, at the southern end of the pass. ${ }^{3}$

The length of the Capel Mounth is not twelve miles, but less than six miles from its southern end below the Capel Burn to Spital of Muick. It would be about twelve miles to the Dee. It would be $a$ very convenient pass between Glen Muick and the Braes of Angus, and may have been a good deal used in the days when the district was more largely populated than now. The late Rev. J. G. Michie, of Dinnet, says :-

"The clachan of Milltown of Crathie was of old a place of much resort. There was there both a ferry and a ford over the Dee, communicating with the south country by the Capel Pass and Glen Clova. It will be remembered that Montrose, in his memorable retreat through Angus to the North, crossed the river here Ist May 1645. ${ }^{4}$ Long after his time refreshments conld be had at the boathouse. In 1696 we learn from the Poll Book that there was a large population in the neighbourhood. In 1801 the mill had disappeared, although the name of Milltown still remained; and, thongh the ferry and ford had ceased to be used, the old boathouse continued to be frequented as an inn until about 1824. It was then abolished as a nuisance." 5

The Capel Mounth road, which started from Glen Clova at about 1000 feet above sea-level, rose in about a mile to 2250 feet, and went

1 This pass over Mount Keen, like others, was much used within living memory by bands of men and women who went over into the south country for harvesting. They were known as "Thravers," from thrave, 24 sheaves of grain, wages being paid accordingly.

- 2 Sometimes, but very rarely, the term "Capel" may derive from capull, a mare.

3 "'There was an Hospital at Spittal (below an ale-house) on the east end of Loch Muick, where there is a pass (called the Caiple Month) to the hills of Clova." - View of the Diocese, p. 640 .

4 This does not mean that Montrose crossed by the Capel Mointh. As he crossed from Dunkeld, the likelihood is that he crossed by what is known as the Cairnwell.

5 Records of Invercauld,.p. 57. 
along most of the way above the 2000 feet level. When nearly, opposite the north end of Loch Muick it descended to 1350 at the Spital of Glen Muick. In winter, like most of the other Mounth passes, it was extremely dangerous, as testified by the numerous snow posts and cairns erected for the guidance of travellers-certain of the cairns, indeed, being erected as memorials of persons who had lost their lives in the pass. ${ }^{1}$ The Capel Mounth is now only a rough track used by shepherds and tourists.

From the Glen Muick road, slightly west of Glenmuick House, an old track-known from smuggling days as a "whisky road"-formed a short cut to the southern portion of the Mount Keen route. It passed southward by the west shoulder of Cairn Leughan, and, orossing the Tanner half-a-mile above the falls, joined the Mount Keen pass at the county boundary. This track kept a good level all the way, avoiding $\dot{0}$ the great dip that the main road makes into Glen Tanner.

A more famous subsidiary path in the Glen Muick region is the "White Mounth" path over Lochnagar. The present name of this famous mountain belongs really to the loch, but it can never be changed now. There is evidence that the old name of Lochnagar was Beinnnan-Ciochan, that is, Hill of the Breasts, in reference to its characteristic peaks. The path to the top is a very old one, but about 1870 Queen Victoria made it a pony track, when the zigzag path-the celebrated "Ladder" - was cut up the face of Cuidhe Crom, where previously the path went straight up.

\section{The Tolmounth.}

This was also a well-known path, that led from the more important Cairnwell road, in Glen Clunie, over into Angus. It left the Cairnwell road above the junction of the Callater Burn with the Clunie, at 1250 feet. Ascending Glen Callater, with Sron Dubh (Black Nose) on the right, it passed along the north-east shore of Loch Callater, passed over the Tolmount (3143) within the 3000 feet contour line, and descended by the zigzag "Jock's Road" into Glen Doll, thence to Glen Clova, where it joined the Capel Mounth road as above described. In the seventeenth century the Tolmounth pass was not suffioiently important to be included in the list of roads over the Grampians. It must have been of considerable importance, however, in the droving period, and, of course, is a notable right-of-way.

\section{The Cairnwell Road.}

This notable pass leads from Perthshire, by Glenshee and Braemar, to the uplands of Aberdeenshire and the northern counties, and has been known by various names-“Carnavalage". (1657), late local

I On 1st May 1892 a party of sixteen cyclists crossed by the Capel Mounth from Glen Muick to Glen Clova. They pushed their bicycles all the way over the mountain path, and finished the day at Forfar. They were the first cyclists to cross the Capel Mounth. See Mountaineering Club Journal, ii. pp. 140-1.

voL. XXXVI. 
pronunciation, "Carnwallak." 1 The writer of the View of the Diucese, c. 1732, gives the name as Carnavalage. ${ }^{2}$ This must be taken as nearer the original form than the present "Cairnwell," and (being almost right in pronunciation) bears out Macdonald's idea that the name has nothing to do with the well, but is really "Carn a' bhealaich," the "Cairn of the Pass."

The Cairnwell is an ancient and well-known pass-the highest carriage road in Britain. The provision of an hospital or hospice there centuries ago indicates that it was well used. ${ }^{3}$ After the period of the Jacobite rebellions it was the recognised route from Perth to Fort George. The road from Perth crossed the Tay near Coupar-Angus, and passed through Blairgowrie at 58 miles. Spital of Glenshee was passed at 77 miles, from which over the Mounth, to Castletown of Braemar-summit 2200 feet above sea-level-was a distance of 15 miles. ${ }^{4}$ From Braemar the line of the road was the Old Deeside Road -over the General Wade bridge of 1762 at Invercauld-to opposite Balmoral, where it turned north-eastward, and, crossing the Gairn by the General Wade bridge at Gairnsheil, still in use, it struck over, as at present, by Tornahaish, Corgarff, and Tomintoul, and thence by Bridge of Brown, Grantown, and Nairn to its destination, Fort George, 164 miles from Perth.

The Cairnwell Pass was not of so much consequence, probably, until after it was formed into a military road by General Wade.' In 1864 the ten miles of road from Cairnwell to Braemar was reconstructed and the gradients improved-and the road diverted in many places-at an expense of $£ 2739,11$ s. 11 d., contributed by the late Prince Consort, and $£ 1138,17 \mathrm{~s} .11 \mathrm{~d}$. contributed by the late Colonel Farquharson of Invercauld. The same year the bridge carrying the road over the Clunie at Braemar was rebuilt at a cost of $£ 1053,2 \mathrm{~s}$. 6d., paid by the four heritors of the parish.

\section{Glen Tilt Route.}

This was not an important road, but it is an ancient route over the 'Mounth, 'and, as connecting with our Old Deeside Road, it is not to be omitted. It is too well known to need description. After leaving Blair Atholl it passes through some of the most beautiful scenery in north Perthshire. Later, and while it is merely a bridle path, the scenery is desolate, and as it comes round into Glen Dee, and turns eastward to the Linn, it touches the wildest scenery in the Grampian range. Pennant, who travelled by this route in 1769 , considered the road through Glen Tilt " the most dangerous and the most horrible I

1'James Macdonald's Place Names of West Aberdeenshire, p. 88. Although often wrong, Macdonald was very careful on such points.

2 View of the Diocese, p. $77 n$.

3 "Ther was an Hospitall at Carnwall (called Shean-Spittal, or Old Hospital) wher ther is a road over the Granpian Hills."-View of the Diocese, p. 542.

* Taylor and Skinner, plates 26 and 27, give the distance as slightly less. 
ever travelled." 1 Others have found it more agreeable. By the ordinary route the distance from Blair Atholl to Braemar is about 25 miles, but experienced mountain travellers sometimes vary the route by crossing the mountains between Glen Tilt and Glen Clunie. ${ }^{2}$

\section{Glen Derry Drove Road from Strathspey.}

This old pass, known as the Lairig-an-Laogh (Pass of the Calf), on the Inverness side of the boundary line, like certain of the others mentioned, is used now only by tourists. But it was once a well-known route, and remains of dwellings that one still sees in Glen Lui show that there were houses by the wayside. It served as a cross-country route between Speyside and Atholl, via Glen Ey, or by the Cairnwell Pass, and was used also in connection with the Old Deeside Road by Braemar eastwards. It could be reached from Speyside (1) from Aviemore, by Coylum Bridge and Loch Morlich, (2) from Boat of Garten, by Kincardine, Rhynie, and the Nethy, and (3) from Nethy Bridge and the lower districts of Speyside, by the road along the valley of the Nethy, a good though rough road still by Kynottin, for Loch Morlich and Cairngorm, on the right hand, or across the Nethy, below Nam Suim, for Glen Derry, on the left. ${ }^{3}$ Through Glen Derry and Glen Lui the route is familiar to all who wish to make the easy ascent of Ben Muic Dhui. from Braemar. In 1776, Rev. Charles Cordiner, of the Episcopal Chapel, Banff, passed along this route, and described the appearance of the place in a letter to Pennant.

"Leaving Lui Beg, an opener but rocky dale on the left, see a charming valley of meadow-ground, with much fine natural grass. The ruins of several stone buildings show that it had been once inhabited; but it is now, as the other pastures of the forest, left to fatten the deer. On the sides of the hills bordering on the valley are many thousand stumps of trees, the remains of woods which have been floated down Lui Water to the Dee.

"From thence by a narrow path, winding among trees, there is an entrance into a dale called Derry, singularly wild and picturesque. . . . Ridges of rocky mountains run along its sides, and these, connected at the farther end, form a magnificent boundary to some miles of pretty level ground." "

Besides all these more or less important routes over the Grampians -connecting with the old Deeside highway, running east and west, and communicating with the country on both sides of it, north and southvarious minor routes were in use that acted as "feeders" for the old highway, or formed convenient passes for districts not otherwise served. These included the Glen Feshie-Geldie Pass, that gave access from the

1 Tour in Scotland, 2nd ed., 1772, pp. 106-7.

2 For the detailed time-table of a party of tourists by this route, in 1908, see Scottish Mountaineering Club Journal, x. 231.

3 The road is now becoming practically impassable for vehicles, but thoroughly good for walking. A few years ago, in a very wet season, the writer cycled it practically all the way from Nethy Bridge to Loch Morlich.

4 Cordiner, Antiquities and Scenery of the North of Scotland;1780, p. 27. Three-quarters of a century later, John Hill Burton found the same route equally delightful. See his Cairngorm Mountains, 1864, pp. 26. et seq. 
upper regions of Strathspey, by way of Braemar, to both Deeside and the south country, the importance of this pass being shown by this, that there was a great market stance at the junction of the Geldie and the Bynack Burns, where the Glen Feshie-Geldie Pass joined that of Glen Tilt. Then there was the rather famous Lairig Ghru, a branch of the Glen Derry route; also the Glen Builg Pass, that was a well-used drove road from the north country beyond the Avon by way of Loch Builg to Braemar on the one, hand, and down Glen Gairn on the other.

With the exception of the Slug Road, Cairn-a'-Mounth, and the Cairnwell Road, all these old passes are out of use, except by tourists and by shepherds and hill-keopers. Certain of them, such as Cryne's Cross Mounth, the Stock Mounth, and the Builg Mounth, are now untrodden even by tourists. Yet they all have their significance, for they not merely affected, each in its own district, the Old Deeside Road - the main road from Aberdeen westwards along the Dee Valley to Kindrochaid (Braemar) - but they had an influence on the growth of civilisation in this whole north-eastern part of Scotland.

Note.-I should like to acknowledge suggestions received, and revision of certain portions of the foregoing paper, from Mr. G. Gordon Jenkins, C.E., Aberdeen.-G. M. F.

\section{BARTHOLOMEW'S NEW ATLAS. ${ }^{1}$}

THE need of a large-scale modern Atlas of the World has long been felt. The large atlases of British production so far available can scarcely be said to have kept abreast of modern geographical development. Geography as a science cannot be expected to receive adequate recognition and widespread acceptance as long as the old style of map, which shows places and boundaries without relation to surface features; is prevalent. There is probably no more satisfactory way of advancing the study of geography than by the general use of a good atlas. Some years ago, in an address to the Royal Geographical Society, Mr. Rudyard Kipling said that "as soon as men begin to talk about anything that really matters some one has to go and get the atlas." The pity is that the atlas is tóo often a bad one, or at least one that fails to elucidate the discussion, as adequate maps might do.

This want is now supplied by the new atlas in the course of production by the Edinburgh Geographical Institute. The name of Bartholomew has long been a guarantee of first-class cartography and high standard of production. The present work enhances the reputation of the firm, and takes its place as the foremost British atlas. More publicity might well be given to the geographer who planned and the firm which

1 The Times Survey Atlas of the World. Prepared at the Edinburgh Geographical Institute under the direction of J. G. Bartholomew, LL.D. London: The Times Office, 1920. To be completed in 37 fortnightly parts. Price 2s. 6d. each part. 